\title{
The Effect of Non Performing Financing (NPF) and Operating Expenses of Operating Income (BOPO) on Return on Equity (ROE) on PT. Bank Bri Syariah, Tbk.
}

\author{
Nofriyanti ${ }^{1}$, Kamaluddin ${ }^{2}$, Sry Lestari $^{3}$, Damri $^{4}$ \\ ${ }^{1}$ IAIN Padangsidimpuan (Perbankan Syariah, FEBI, IAIN Padangsidimpuan) \\ ${ }^{2}$ IAIN Padangsidimpuan (Dakwah Syariah, FEBI, IAIN Padangsidimpuan) \\ ${ }^{3}$ IAIN Padangsidimpuan (Perbankan Syariah, FEBI, IAIN Padangsidimpuan) \\ ${ }^{4}$ IAIN Padangsidimpuan (Ekonomi Syariah, FEBI, IAIN Padangsidimpuan) \\ Elnasriwanna@gmail.com ${ }^{1}$, kamaluddin@iain-padangsidimpuan.ac.id ${ }^{2}$, sryletari@iain- \\ padangsidimpuan.ac.id $^{3}$, damri@iain-padangsidimpuan.ac.id $^{4}$
}

\begin{abstract}
ABSTRAK
Latar belakang penelitian ini adalah tidak sesuainya teori dengan fakta. Berdasarkan data laporan keuangan yang diperoleh dari PT. Bank BRI Syraiah, Tbk. Periode 2011-2019 cenderung mengalami fluktuasi. Rasio keuangan yang dapat memengaruhi naik turunnya nilai variabel Return On Equity dalam penelitian ini dilihat dari peningkatan dan penurunan pada variabel Non Performing Financing dan variabel Biaya Operasional Pendapatan Operasional. Rumusan masalah dalam penelitian ini adalah apakah ada pengaruh Non Performing Financing dan Biaya Operasional Pendapatan Operasional terhadap Return On Equity pada PT. Bank BRI Syariah, Tbk. Periode 2011-2019. Penelitian ini bertujuan untuk mengetahui pengaruh Non Performing Financing dan Biaya Operasional Pendapatan Operasional terhadap Return On Equity pada PT. Bank BRI Syariah, Tbk. Periode 2011-2019 secara parsial dan simultan. Penelitian ini membahas tentang laporan keuangan yang berkaitan dengan teori variabel Non Performing Financing dan variabel Biaya Operasional Pendapatan Operasional terhadap variabel Return On Equity. Dan yang berkaitan dengan bidang-bidang ilmu perbankan syariah lainnya. Jenis penelitian ini adalah penelitian kuantitatif, sumber data yang digunakan adalah data sekunder melalui www.brisyariah.co.id. Sampel penelitian ini sebanyak 36 dengan analisis data yang digunakan adalah regresi linear berganda, dengan melakukan uji statistik deskriptif, uji normalitas, uji linearitas, uji asumsi klasik, uji hipotesis, uji koefisien determinasi $\mathrm{R}^{2}$, serta uji $\mathrm{F}$, dan data diolah dengan bantuan Software Eviews 9. Berdasarkan hasil penelitian secara parsial variabel Non Performing Financing berpengaruh secara signifikan terhadap Return On Equity, hal ini dibuktikan dengan analisis uji t. Dan pada variabel Biaya Operasional Pendapatan Operasional secara parsial berpengaruh secara signifikan terhadap Return On Equity, hal ini dibuktikan dengan analisis uji t. Kemudian secara simultan variabel Non Performing Financing dan Biaya Operasional Pendapatan Operasional berpengaruh secara bersama-sama terhadap Return On Equity.

Kata Kunci: Biaya Operasional Pendapatan Operasional, Non Performing Financing, Return On Equity
\end{abstract}

\section{ABSTRACT}

The background of this research is the incompatibility of theory with facts. Based on financial report data obtained from PT. Bank BRI Syria, Tbk. The period 2011-2019 tends to fluctuate. Financial ratios that can affect the rise and fall of the Return On Equity variable in 
this study are seen from the increase and decrease in the Non Performing Financing variable 


\begin{tabular}{|c|c|c|c|c|}
\hline 2019 & I & 2,54 & 4,34 & 95,67 \\
\cline { 2 - 5 } & II & 1,51 & 4,51 & 96,74 \\
\cline { 2 - 5 } & III & 1,60 & 3,97 & 96,78 \\
\cline { 2 - 5 } & IV & 1,57 & 3,38 & 96,80 \\
\hline
\end{tabular}

Sumber:www.brisyariah.co.id (data diolah)

Berdasarkan pada tada tabel 1 diatas dapat dilihat bahwa Return On Equity (ROE) pada tahun 2011 triwulan 2 mengalami peningkatan sebesar 0,29 persen, begitu juga dengan Non Performing Financig (NPF) pada tahun 2011 triwulan 2 juga mengalami peningkatan sebesar 1,07 persen. Pada tahun 2013 triwulan 2 Return On Equity (ROE) mengalami penurunan sebesar 3,82 persen, begitu juga dengan Non Performing Financig (NPF) pada tahun 2013 triwulan 2 juga mengalami penurunan sebesar 0,07 persen. Pada tahun 2019 triwulan 4 Return On Equity (ROE) mengalami penurunan sebesar 0,03 persen, begitu juga dengan Non Performing Financing (NPF) pada tahun 2019 triwulan 4 juga mengalami penurunan sebesar 0,59 persen.

Kemudian Biaya Operasional Pendapatan Operasional (BOPO) pada tahun 2013 triwulan 3 mengalami penurunan sebesar 6,75 persen, begitu juga dengan Return On Equity (ROE) pada tahun 2013 triwulan 3 juga mengalami penurunan sebesar 1,65 persen. Pada tahun 2014 triwulan 4 Biaya Operasional Pendapatan Operasional (BOPO) mengalami peningkatan sebesar 2,42 persen, begitu juga dengan Return On Equity (ROE) pada tahun 2014 triwulan 4 juga mengalami peningkatan sebesar 0,08 persen. Pada tahun 2018 triwulan 2 Biaya Operasional Pendapatan Operasional (BOPO) mengalami penurunan sebesar 0,83 persen, begitu juga dengan Return On Equity (ROE) pada tahun 2018 triwulan 2 juga mengalami penurunan sebesar 0,55 persen.

Berdasarkan teori apabila Non Performing Financing (NPF) semakin besar maka akan mengakibatkan menurunnya Return On Equity (ROE), yang juga berarti kinerja keuangan bank yang menurun karena risiko kredit semakin besar. Begitu pula sebaliknya, jika Non Performing Financing (NPF) turun, maka Return On Equity (ROE) akan semakin meningkat, sehingga kinerja keuangan bank dapat dikatakan semakin baik (Ali Idrus 2018:86). Namun dilihat dari fenomena di atas bahwa peningkatan dan penurunan dari Non Performing Financing (NPF) tidak memberikan pengaruh terhadap naik turunnya Return On Equity (ROE), maka hal ini tidak sesuai dengan teori yang ada.

Biaya Operasional Pendapatan Operasional (BOPO) juga dapat mempengaruhi Return On Equity (ROE) selain Non Performing Financing (NPF). Berdasarkan teori dimana semakin kecil Biaya Operasional Pendapatan Operasional (BOPO) berarti semakin efisien biaya operasional yang dikeluarkan bank yang bersangkutan sehingga kemungkinan suatu bank dalam kondisi bermasalah semakin kecil (Pandia 2012). Dapat disimpulkan bahwa apabila Biaya Operasional Pendapatan Operasional (BOPO) mengalami penurunan maka Return On Equity (ROE) akan mengalami peningkatan dan sebaliknya apabila Biaya Operasional Pendapatan Operasional (BOPO) mengalami peningkatan maka Return On Equity (ROE) akan mengalami penurunan. Setiap peningkatan pendapatan operasi akan berakibat pada berkurangnya laba sebelum pajak yang pada akhirnya akan menurunkan laba (Zulvia 2020:53). Namun dilihat dari fenomena di atas hal ini tidak sesuai dengan teori yang ada.

\section{B. METODE}

Lokasi penelitian ini dilakukan pada PT. Bank BRI Syariah, Tbk. Adapun waktu penelitian dilaksanakan mulai dari Januari 2020 sampai dengan April 2021, dengan data yang diperoleh bersumber dari data sekunder yang diambil dari website resmi www.brisyariah.co.id. dengan populasi seluruh laporan keuangan triwulan NPF, BOPO dan ROE pada PT. Bak BRI Syariah periode tahun 2011-2019 yang dipublikasikan dalam laporan keuangan PT. Bank BRI Syariah yaitu sebanyak 36 populasi. Adapun sampel dalam penelitian ini adalah seluruh laporan keuangan triwulan NPF ,BOPO dan ROE pada PT.Bank BRI Syariah periode 2011-2019 yang 
dipublikasikan dalam laporan keuangan PT. Bank BRI Syariah yaitu sebanyak 36 sampel.

Dalam penelitian ini teknik pengumpulan data yang digunakan adalah metode dokumentasi, yaitu melalui pengumpulan data sekunder yang diperoleh dari laporan keuangan PT. Bank BRI Syariah periode 2011-2019. Kemudian akan diolah menggunakan software Eviews 9 dengan menggunakan metode analisis deskriptif, uji normalitas, uji asumsi klasik yaitu uji multikolinearitas, uji heteroskedastisitas, dan uji autokolerasi, uji koefisien determinasi, uji regresi linear berganda, uji hipotesis yaitu uji $t$ dan uji F.

\section{HASIL DAN PEMBAHASAN}

\section{Analisis Statistik Deskriptif}

Statistik deskriptif adalah statistik yang digunakan untuk menganalisa data dengan cara mendeskripsikan atau menggambarkan data yang telah terkumpul sebagaimana adanya tanpa bermaksud membuat kesimpulan yang berlaku untuk umum atau generalisasi.

Tabel 2

Hasil Uji Statistik Deskriptif

\begin{tabular}{|c|r|r|r|}
\hline & ROE & NPF & BOPO \\
\hline Mean & 5.864167 & 3.375833 & 93.70167 \\
\hline Median & 6.040000 & 3.630000 & 93.81500 \\
\hline Maximum & 18.63000 & 4.970000 & 101.3800 \\
\hline Minimum & 0.290000 & 1.700000 & 80.80000 \\
\hline Std. Dev. & 4.378628 & 0.945441 & 4.559663 \\
\hline Skewness & 0.835569 & 0.407955 & -0.528433 \\
\hline Kurtosis & 3.491149 & 1.896233 & 3.261133 \\
\hline Sum & 211.1100 & 121.5300 & 3373.260 \\
\hline $\begin{array}{c}\text { Sum Sq. } \\
\text { Dev. }\end{array}$ & 671.0333 & 31.28508 & 727.6685 \\
\hline $\begin{array}{c}\text { Observatio } \\
\text { ns }\end{array}$ & 36 & 36 & 36 \\
\hline
\end{tabular}

Sumber: data diolah Eviews 9

Berdasarkan tabel 2 di atas dapat dilihat bahwa variabel NPF, jumlah data (N) adalah 36, dengan rata-rata NPF yaitu 3,37 persen, minimumnya adalah 1,70 persen, maksimumnya adalah 4,97 persen, sum sebesar
121,53 persen, dan standar deviasi sebesar 0,94 persen.

Untuk variabel BOPO, jumlah data (N) adalah 36, dengan rata-rata BOPO 93,70 persen, minimumnya adalah 80,80 persen, maksimumnya adalah 101,38 persen, sum sebesar 3373,26 persen, dan standar deviasi sebesar 4,55 persen.

Untuk variabel ROE, jumlah data (N) adalah 36, dengan rata-rata ROE yaitu 5,86 persen, minimumnya adalah 0,29 persen, maksimumnya adalah 18,63 persen,sum sebesar 211,11 persen, dan standar deviasi sebesar 4,37 persen.

2. Uji Normalitas

Uji normalitas bertujuan mengetahui apakah masing-masing variabel berdistribusi normal atau tidak. Kriteria pengujian normalitas pada program eviews adalah dengan uji Jarque-Bera. Dimana jika pada hasil uji Jarque-Bera $<$ chi square maka data pada model berdistribusi normal.

Tabel 3

Hasil Uji Normalitas

\begin{tabular}{|c|c|c|c|}
\hline & ROE & NPF & BOPO \\
\hline Jarque-Bera & 4.550893 & 2.826017 & 1.777734 \\
\hline Probability & 0.102751 & 0.243410 & 0.411121 \\
\hline Sum & 211.1100 & 121.5300 & 3373.260 \\
\hline Sum Sq. Dev. & 671.0333 & 31.28508 & 727.6685 \\
\hline Observations & 36 & 36 & 36 \\
\hline
\end{tabular}

Sumber: data diolah eviews 9

Berdasarkan hasil di atas terlihat bahwa nilai Jarque-Bera dari ROE sebesar 4,550893, nilai Jarque-Bera NPF sebesar 2,826017 dan nilai JarqueBera BOPO sebesar 1,777734, sementara nilai chi square dengan melihat nilai signifikan yang peneliti gunakan dalam hal ini adalah sebesar 0,05 atau 5\% sehingga nilai chi square yang didapat sebesar 50,99846, maka dapat dilihat bahwa nilai JarqueBera dari semua variabel baik dependen maupun independen lebih kecil dari nilai chi square,dapat disimpulkan bahwa data dalam penelitian ini berdistribusi normal.

3. Uji Asumsi Klasik

\section{a. Uji Multikolinearitas}

Uji multikolinearitas digunakan untuk mengetahui ada atau tidaknya penyimpangan asumsi klasik multikolinearitas, yaitu adanya hubungan linear antara variabel independen dalam model regresi. Untuk mendeteksi masalah 
multikolinearitas dapat menggunakan metode VIF (Varian Inflation Factor), dimana jika nilai VIF > 10 maka terdapat multikolinearitas dalam model.

Tabel 4

Hasil Uji Multikolinearitas

\begin{tabular}{|c|c|c|c|}
\hline \multicolumn{4}{|c|}{ Variance Inflation Factors } \\
\hline \multicolumn{4}{|c|}{ Date: $12 / 23 / 20$ Time: $15: 23$} \\
\hline \multicolumn{4}{|c|}{ Sample: 2011Q1 2019Q4 } \\
\hline \multicolumn{4}{|c|}{ Included observations: 36} \\
\hline \multirow{3}{*}{ Variab } & Coefficient & Uncentered & Centered \\
\hline & & & \\
\hline & Variance & VIF & VIF \\
\hline C & 51.38430 & 435.4242 & NA \\
\hline NPF & 0.140572 & 14.61028 & 1.035180 \\
\hline ВOРО & 0.006044 & 450.6901 & 1.035180 \\
\hline
\end{tabular}

Sumber: data diolah Eviews 9

Hasil uji multikolinearitas, dapat dilihat tabel di atas kolom centered VIF. Nilai VIF untuk variabel NPF sebesar 1,035180. Sementara nilai VIF BOPO sebesar 1,035180. Nilai dari kedua variabel tidak ada yang lebih besar dari 10 maka dapat disimpulkan bahwa tidak terjadi multikolinearitas pada penelitian ini.

\section{b. Uji Heteroskedastisitas}

Uji heteroskedastisitas pada penelitian ini di uji dengan uji white yang pada prinsipnya meregresi residual yang dikuadratkan dengan variabel independen. Dari persamaan regresi tersebut didapatkan nilai R2 untuk menghitung c2 dimana c2 $=\mathrm{n} \times \mathrm{R} 2$. Pengujiannya adalah jika c2 hitung < c2 tabel, maka hipotesis alternatif adanya heteroskedastisitas dalam model ditolak.

Tabel 5

Hasil Uji Heteroskestisitas

\begin{tabular}{|c|c|c|c|}
\hline \multicolumn{4}{|c|}{ Heteroskedasticity Test: White } \\
\hline F-statistic & 3.855391 & Prob. $F(2,33)$ & 0.0313 \\
\hline $\begin{array}{l}\text { Obs*R-squared } \\
\text { Scaled explained }\end{array}$ & 6.818541 & Prob. Chi-Square(2) & 0.0331 \\
\hline SS & 8.240740 & Prob. Chi-Square(2) & 0.0162 \\
\hline
\end{tabular}

Sumber: data diolah Eviews 9

Berdasarkan hasil uji heteroskedastisitas di atas, dapat diketahui bahwa nilai c2hitung sama dengan 6,818541 dan nilai c2tabel dengan signifikan 0,05 adalah sebesar 50,99. Maka nilai c2 hitung < c2 tabel $(6,818541<50,99)$, sehingga dapat disimpulkan bahwa tidak terdapat heteroskedastisitas pada penelitian ini.

\section{c. Uji Autokolerasi}

Uji autokolerasi digunakan untuk mengetahui apakah dalam satu model regresi linear ada kolerasi antara kesalahan pengganggu pada periode $\mathrm{t}$ dengan kesalahan pada periode $\mathrm{t}-1$ atau periode sebelumnya. Untuk mendeteksi gejala autokolerasi dapat menggunakan uji Durbin-Waston (D-W).

Tabel 6

Hasil Uji Autokorelasi

\begin{tabular}{|c|c|c|c|c|}
\hline \multicolumn{5}{|c|}{$\begin{array}{l}\text { Dependent Variable: ROE } \\
\text { Method: Least Squares } \\
\text { Sample: 2011Q1 2019Q4 } \\
\text { Included observations: } 36\end{array}$} \\
\hline Variable & Coefficient & Std. Error & t-Statistic & Prob. \\
\hline C & 82.92458 & 7.168284 & 11.56826 & 0.0000 \\
\hline NPF & -1.088630 & 0.374929 & -2.903560 & 0.0065 \\
\hline BOPO & -0.783181 & 0.077741 & -10.07421 & 0.0000 \\
\hline R-squared & 0.791075 & \multicolumn{2}{|c|}{ Mean dependent var } & 5.864167 \\
\hline Adjusted R-squared & 0.778413 & \multicolumn{2}{|c|}{ S.D. dependent var } & 4.378628 \\
\hline Sum squared resid & 140.1956 & \multicolumn{2}{|c|}{ Schwarz criterion } & 4.496023 \\
\hline Log likelihood & -75.55314 & \multirow{2}{*}{\multicolumn{2}{|c|}{$\begin{array}{c}\text { Hannan-Quinn criter. } \\
\text { Durbin-Watson stat }\end{array}$}} & 4.410121 \\
\hline F-statistic & 62.47574 & & & 2.324919 \\
\hline
\end{tabular}

Sumber: data diolah Eviews 9

Berdasarkan hasil uji autokorelasi di atas, dapat diketahui bahwa nilai DW adalah sebesar 2,324919, yang berarti bahwa nilai du < DW $<4$ - du $(1,5872<2,324919<2,4128)$ sehingga dapat disimpulkan bahwa tidak terjadi autokorelasi pada penelitian ini.

4. Uji Hipotesis

a. Uji Statistik t

Uji statistik $\mathrm{t}$ digunakan untuk menguji pengaruh masing-masing variabel independen yang digunakan terhadap variabel dependen dengan menganggap variabel lain bernilai konstan. Adapun kriteria pengujiannya adalah sebagai berikut:

1) $\mathrm{HO}$ diterima dan $\mathrm{Ha}$ ditolak apabila thitung

$<$ ttabel atau nilai signifikan > 0,05. Artinya

variabel bebas tidak berpengaruh secara

signifikan terhadap variabel terikat. 
2) HO ditolak dan Ha diterima apabila Jika thitung $>$ ttabel atau nilai signifikan $<0,05$.

Artinya variabel bebas berpengaruh secara signifikan terhadap variabel terikat.

Tabel 7

Hasil Uji t

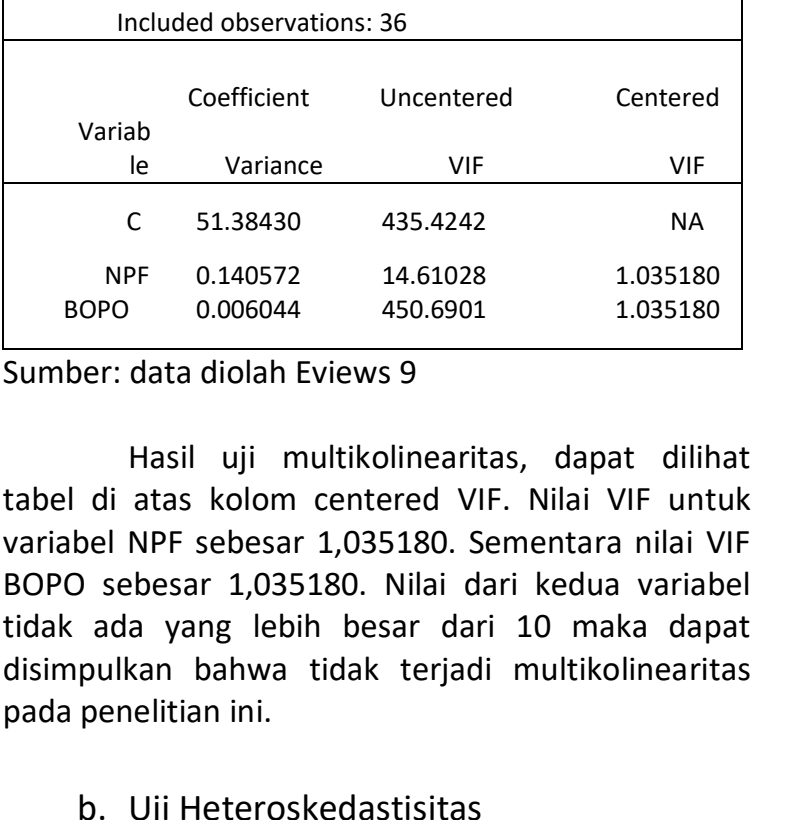

Sumber: data diolah Eviews 9

Berdasarkan hasil uji t di atas, dapat diketahui bahwa nilai probability variabel NPF sebesar 0,0065 , dan probability untuk variabel BOPO sebesar 0,0000 , dan taraf signifikan yang digunakan adalah 0,05. Maka dapat disimpulkan bahwa:

(1) NPF secara parsial berpengaruh secara signifikan terhadap ROE, dibuktikan dengan $0,0065<0,05$.

(2) BOPO secara parsial berpengaruh secara signifikan terhadap ROE, dibuktikan dengan $0,0000<0,05$.

b. Uji Statistik F

Uji F digunakan untuk menguji pengaruh variabel independen secara keseluruhan
POINT Vol. 2, No. 2, Jul 2021 terhadap dependen. Adapun kriteria pengujian yang digunkan adalah sebgai berikut:

1) $\mathrm{HO}$ diterima dan $\mathrm{Ha}$ ditolak apabila Fhitung < Ftabel atau nilai signifikansi > 0,05. Artinya variabel bebas tidak berpengaruh secara signifikan terhadap variabel terikat.

2) HO ditolak dan Ha diterima apabila Fhitung $>$ Ftabel nilai signifikansi $<0,05$. Artinya variabel bebas berpengaruh secara signifikan terhadap variabel terikat.

Tabel 8

Hasil Uji F

\begin{tabular}{|c|c|c|c|c|}
\hline \multicolumn{5}{|c|}{$\begin{array}{l}\text { Dependent Variable: ROE } \\
\text { Method: Least Squares } \\
\text { Date: 12/23/20 Time: 15:29 } \\
\text { Sample: 2011Q1 2019Q4 } \\
\text { Included observations: } 36\end{array}$} \\
\hline Variable & Coefficient & Std. Error & t-Statistic & Prob. \\
\hline $\begin{array}{c}\mathrm{C} \\
\mathrm{NPF} \\
\text { BOPO }\end{array}$ & $\begin{array}{c}82.92458 \\
-1.088630 \\
-0.783181\end{array}$ & $\begin{array}{l}7.168284 \\
0.374929 \\
0.077741\end{array}$ & $\begin{array}{r}11.56826 \\
-2.903560 \\
-10.07421\end{array}$ & $\begin{array}{l}0.0000 \\
0.0065 \\
0.0000\end{array}$ \\
\hline $\begin{array}{l}\text { R-squared } \\
\text { Adjusted R-squared } \\
\text { S.E. of regression } \\
\text { Sum squared resid } \\
\text { Log likelihood } \\
\text { F-statistic } \\
\text { Prob(F-statistic) }\end{array}$ & $\begin{array}{l}0.791075 \\
0.778413 \\
2.061153 \\
140.1956 \\
-75.55314 \\
62.47574 \\
0.000000\end{array}$ & $\begin{array}{r}\text { Mean depe } \\
\text { S.D. depe } \\
\text { Akaike inf } \\
\text { Schwarz } \\
\text { Hannan-Qu } \\
\text { Durbin-W }\end{array}$ & $\begin{array}{l}\text { dent var } \\
\text { dent var } \\
\text { criterion } \\
\text { riterion } \\
\text { nn criter. } \\
\text { tson stat }\end{array}$ & $\begin{array}{l}5.864167 \\
4.378628 \\
4.364063 \\
4.496023 \\
4.410121 \\
2.324919\end{array}$ \\
\hline
\end{tabular}

Sumber: data diolah Eviews 9

Berdasarkan hasul uji $\mathrm{F}$ di atas dapat diketahui bahwa nilai probability (F-statstik) dari kedua variabel independen sebesar 0,000000 dan nilai signifikan adalah 0,05. Maka dapat disimpulkan bahwa NPF dan BOPO secara simultan berpengaruh terhadap ROE, dibuktikan dengan 0,000000 <0,05.

5. Uji Koefisien Determinasi (R2)

Uji koefisien determinasi (R2) pada intinya mengukur seberapa jauh kemampuan model dalam menerangkan variasi variabel dependen. Nilai koefisien determinasi dapat diukur oleh nilai R2. 
Tabel 9

Uji Koefisien Determinasi

\begin{tabular}{|c|c|c|c|c|}
\hline $\begin{array}{l}\text { Depender } \\
\text { Method: } \\
\text { Sample: } 2 \\
\text { Included }\end{array}$ & $\begin{array}{l}\text { Variable: R } \\
\text { Least Square } \\
\text { 11Q1 } 20190 \\
\text { oservations: }\end{array}$ & & & \\
\hline Variable & Coefficient & Std. Error & t-Statistic & Prob. \\
\hline c & 82.92458 & 7.168284 & 11.56826 & 0.0000 \\
\hline NPF & -1.088630 & 0.374929 & -2.903560 & 0.0065 \\
\hline BOPO & -0.783181 & 0.077741 & -10.07421 & 0.0000 \\
\hline R-squared & 0.791075 & \multicolumn{2}{|c|}{ Mean dependent var } & 5.864167 \\
\hline Adjusted R-squared & 0.778413 & \multicolumn{2}{|c|}{ S.D. dependent var } & 4.378628 \\
\hline S.E. of regression & 2.061153 & \multicolumn{2}{|c|}{ Akaike info criterion } & 4.364063 \\
\hline Sum squared resid & 140.1956 & \multicolumn{2}{|c|}{ Schwarz criterion } & 4.496023 \\
\hline Log likelihood & -75.55314 & \multirow{2}{*}{\multicolumn{2}{|c|}{$\begin{array}{l}\text { Hannan-Quinn criter. } \\
\text { Durbin-Watson stat }\end{array}$}} & 4.410121 \\
\hline F-statistic & 62.47574 & & & 2.324919 \\
\hline
\end{tabular}

Sumber: data diolah Eviews 9

Berdasarkan hasil uji di atas dapat diketahui bahwa nilai R2 sebesar 0,791075 atau 79,10 persen hasil ini menunjukkan bahwa variabel NPF dan BOPO berpengaruh secara simultan terhadap ROE. Sedangkan 20,90 persen dipengaruhi oleh variabel lain yang tidak dimasukkan dalam penelitian ini.

6. Analisis Regresi Linear Berganda

Analisis regresi linear berganda digunakan untuk mengetahui pengaruh variabel independen terhadap variabel dependen yang dianalisis menggunakan Eviews 9. Berikut hasil analisis yang diperoleh:

Tabel 10

Hasil Analisis Regresi Linear Berganda

\begin{tabular}{|c|c|c|c|c|}
\hline $\begin{array}{r}\text { Dep } \\
\mathrm{M} \\
\text { Date: } \\
\text { San } \\
\text { Incl }\end{array}$ & $\begin{array}{l}\text { dent Variabl } \\
\text { od: Least Squ } \\
\text { e: 2011Q1 } 20 \\
\text { ed observatio }\end{array}$ & $\begin{array}{l}\text { ROE } \\
\text { res } \\
15: 29 \\
9 Q 4 \\
\text { s: } 36\end{array}$ & & \\
\hline Variable & Coefficient & Std. Error & t-Statistic & Prob. \\
\hline C & 82.92458 & 7.168284 & 11.56826 & 0.0000 \\
\hline NPF & -1.088630 & 0.374929 & -2.903560 & 0.0065 \\
\hline BOPO & -0.783181 & 0.077741 & -10.07421 & 0.0000 \\
\hline
\end{tabular}

Sumber: data diolah Eviews 9

Adapun persamaan regresi linear berganda yang digunakan dalam penelitian ini adalah sebagai berikut:

$$
\begin{aligned}
& \text { ROE }=82,92458+(-1,088630) N P F+(- \\
& 0,783181) \text { BOPO }+7,168284
\end{aligned}
$$

Persamaan di atas dapat diartikan sebagai berikut:

a. Konstanta sebesar 82,92458 artinya apabila variabel NPF dan BOPO dianggap konstan atau 0 maka, nilai ROE sebesar 82,92458 persen.

b. Nilai koefisien NPF sebesar $-1,088630$ dengan nilai negatif. Hal ini berarti bahwa setiap peningkatan 1 persen NPF maka ROE menurun sebesar 1,088630 persen dengan asumsi variabel lain konstan.

c. Nilai koefisien BOPO sebesar -0,783181 dengan nilai negatif. Hal ini berarti bahwa setiap peningkatan 1 persen BOPO maka ROE menurun sebesar 0,783181 persen dengan asumsi variabel lain konstan.

d. Standard error yaitu angka yang menunjukkan kemampuan untuk memprediksikan variabel dependen. Semakin kecil angka ini maka model regresi semakin tepat digunakan.

Pembahasan Hasil Penelitian

Berdasarkan penelitian yang dilakukan oleh peneliti dari mengolah data melalui aplikasi software eviews 9 maka hasil penelitian sebagai berikut:

1. Berdasarkan hasil analisis determinasi diperoleh R2 sebesar 0,791075 atau 79,10 persen. Hal ini menunjukkan bahwa variabel independen (NPF dan BOPO) berpengaruh terhadap variabel dependen (ROE) sebesar 0,791075 atau 79,10 persen. Sedangkan sisanya sebesar 20,90 persen dipengaruhi oleh variabel lain yang tidak dimasukkan dalam penelitian ini. 
2. Pengaruh NPF terhadap ROE pada PT. Bank BRI Syariah, Tbk.

Dari hasil uji t diketahui bahwa variabel NPF berpengaruh secara signifikan terhadap ROE, dibuktikan dengan nilai probability variabel NPF sebesar 0,0065 dan taraf signifikan yang digunakan sebesar 0,05 persen maka dapat disimpulakan 0,0065 $<0,05$ sehingga dapat disimpulkan bahwa NPF berpengaruh secara signifikan terhadap ROE. Penelitian ini didukung oleh hasil penelitian terdahulu yang dilakukan oleh Ulfa Mariyatul Aini (2020) dimana NPF secara parsial berpengaruh terhadap ROE. penelitian ini juga sejalan dengan dengan teori yang dikutip dari dari jurnal penelitian yang dilakukan oleh Ali Idrus yang menyatakan bahwa apabila NPF semakin besar maka akan mengakibatkan menurunnya $\mathrm{ROE}$, yang juga berarti kinerja keuangan bank yang menurun kerena resiko kredit semakin besar. Begitu pula sebaliknya, jika NPF menurun, maka ROE akan semakin meningkat, sehingga kinerja keuangan bank dapat dikatakan semakin baik (Ali Idrus 2018).

3. Pengaruh BOPO terhadap ROE pada PT.

Bank BRI Syariah, Tbk.

Dari hasil uji t dapat dilihat bahwa nilai probability untuk BOPO sebesar 0,0000 dan taraf signifikan yang digunakan sebesar 0,05 persen maka dapat disimpulkan bahwa 0,0000 $<0,05$ sehingga dapat disimpulkan bahwa variabel BOPO pada penelitian ini berpengaruh signifikan terhadap ROE. Hasil tersebut didukung oleh penelitian yang dilakukan Maroni dan Saur Costanius Simamora (2020) dimana $N P L, L D R$, dan BOPO berpengaruh negatif dan signifikan terhadap ROE. Hal ini juga sejalan dengan teori Frianto Pandia, yang menyatakan semakin kecil BOPO berarti semakin efisien biaya operasional yang dikeluarkan bank yang bersangkutan sehingga suatu bank dalam kondisi bermasalah semakin kecil (Pandia 2012: 72).
POINT Vol. 2, No. 2, Jul 2021

4. Pengaruh NPF dan BOPO terhadap ROE pada PT. Bank BRI Syariah, Tbk.

Hasil uji simultan (F) dapat dijelaskan bahwa nilai probability dari kedua variabel independen sebesar 0,000000 dan nilai signifikan adalah 0,05 persen maka dapat disimpulkan bahwa $0,000000<0,05$ sehingga dapat diambil kesimpulan bahwa NPF dan BOPO secara simultan berpengaruh signifikan terhadap ROE. Hal ini didukung oleh penelitian yang dilakukan oleh Monica (2019) dimana ditemukan hasil bahwa secara bersama-sama variabel CAR, NPL, NIM, BOPO, dan LDR berpengaruh terhadap ROE perusahaan yang terdaftar di Bank Indonesia.

\section{PENUTUP}

\section{Kesimpulan}

Berdasarkan hasil penelitian dan pembahasan yang telah dipaparkan pada bab sebelumnya, maka dapat ditarik kesimpulan terkait Pengaruh NPF dan BOPO terhadap ROE pada PT. Bank BRI Syariah, Tbk. yaitu sebagai berikut:

1) Secara parsial variabel NPF bepengaruh signifikan terhadap ROE, yang dibuktikan dengan analisis uji t, bahwa variabel NPF memiliki nilai signifikan $<0,05$ yaitu $(0,0065<0,05)$. Artinya variabel bebas berpengaruh secara signifikan terhadap variabel terikat.

2) Secara parsial variabel BOPO berpengaruh signifikan terhadap ROE. Dibuktikan dengan analisis uji t, bahwa variabel BOPO memiliki nilai signifikan < 0,05 yaitu $(0,0000<0,05)$. Artinya variabel bebas berpengaruh secara signifikan terhadap variabel terikat.

3) Secara simultan variabel NPF dan BOPO berpengaruh signifikan terhadap ROE, 
yang dibuktikan uji $F$, dengan nilai signifikansi $<0,05$ yaitu $(0,000000<$ 0,05). Artinya variabel bebas berpengaruh secara signifikan terhadap variabel terikat.

\section{Saran}

Semoga adanya peningkatan biaya operasional di masa yang akan datang.

\section{DAFTAR PUSTAKA}

Anelia Anggraeny. "Pengaruh Financing To Deposit Ratio (FDR) Dan Non Perfoming Financing (NPF) Terhadap Return On Equity (ROE)."

Djamil, Faturrahman. 2012. Penyelesaian Bermasalah Di Bank Syariah. Jakarta: Sinar Grafika.

Fahmi, Irham. 2013. Analisis Laporan Keuangan. Bandung: Alfabeta.

Harmono. Manajemen Keuangan, Berbasis Balanced Scorecard Pendekatan Teori, Kasus, Dan Riset Bisnis. Jakarta: PT Bumi Aksara, 2014.

Idrus, Ali. "Pengaruh Faktor Internal dan Eksternal Terhadap Return On Equity (ROE)." Misykat Al-Anwar Jurnal Kajian Islam Dan Masyarakat 29, no. 2 (July 31, 2018).

Ismail. Akuntasi Bank, Teori Aplikasi Dalam Ruiah. Jakarta: Kencana, 2011.

Kasmir. 2012. Analisis Laporan Keuangan. Jakarta: PT Raja Grafindo Parsada.

Pandia, Frianto. 2012. Manajemen Dana Dan Kesehatan Bank. Jakarta: PT Rineka Cipta.
R. Ade Sasongko Pramudhito. 2014. "Analisis pengaruh CAR, NPF, BOPO,FDR, dan NCOM terhadap Profitabilitas Bank Umum Syariah di Indonesia (Studi Kasus Pada Bank Umum Syarah di Indonesia Periode 2008-2012)." Skripsi, Universitas Diponegoro Semarang.

Rodiyah, Winda Aisyatur, and Sri Sulasmiyati. "Pengaruh Return On Investment (ROI), Return On Equity (ROE), Earning Per Share (EPS) Dan Economic Value Added (EVA) Terhadap Harga Saham (Studi Pada Perusahaan Sub Sektor Property Dan Real Estate Yang Terdaftar Di Bursa Efek Indonesia (BEI) Periode 2012 -." Jurnal Administrasi Bisnis 59, no. 1 (June 29, 2018).

Siregar, Budi Gautama. 2016.“Analisis Rasio Keuangan Dalam Menilai Kinerja Perusahaan."

Sofyan Mulazid, Ade. 2017. "Analisis Pengaruh DPK, NPF,CAR, Modal Inti dan Marjin Keuntungan Terhadap Pembiayaan Murabahah." Jurnal Ekonomi dan Bisnis Islam.

Sulhan dan Ely Siswanto. 2008. Manajemen Bank Konvensioanl dan Syariah. Malang: UIN Malang.

Wangsawidjaja Z, A. 2012. Pembiayaan Bank Syariah. Jakarta: PT Gramedia Pustaka Utama.

Washar, Yoga Mauluddin, and Suwitho. "Pengaruh Leverage Terhadap ROE Pada Perusahaan Property Dan Real Estate Yang Terdaftar Di BEI." Jurnal IImu Dan Rset Manajemen 8, no. 6 (2019).

Zulvia, Yolandafitri. 2020. "Faktor-Faktor yang Mempengaruhi Kinerja Keuangan Bank Syariah Indonesia." Jurnal Benefita 5, hlm. 53. 
yang dibuktikan uji $F$, dengan nilai signifikansi $<0,05$ yaitu $(0,000000<$ 0,05). Artinya variabel bebas berpengaruh secara signifikan terhadap variabel terikat.

\section{Saran}

Semoga adanya peningkatan biaya operasional di masa yang akan datang.

\section{DAFTAR PUSTAKA}

Anelia Anggraeny. "Pengaruh Financing To Deposit Ratio (FDR) Dan Non Perfoming Financing (NPF) Terhadap Return On Equity (ROE)."

Djamil, Faturrahman. 2012. Penyelesaian Bermasalah Di Bank Syariah. Jakarta: Sinar Grafika.

Fahmi, Irham. 2013. Analisis Laporan Keuangan. Bandung: Alfabeta.

Harmono. Manajemen Keuangan, Berbasis Balanced Scorecard Pendekatan Teori, Kasus, Dan Riset Bisnis. Jakarta: PT Bumi Aksara, 2014.

Idrus, Ali. "Pengaruh Faktor Internal dan Eksternal Terhadap Return On Equity (ROE)." Misykat Al-Anwar Jurnal Kajian Islam Dan Masyarakat 29, no. 2 (July 31, 2018).

Ismail. Akuntasi Bank, Teori Aplikasi Dalam Ruiah. Jakarta: Kencana, 2011.

Kasmir. 2012. Analisis Laporan Keuangan. Jakarta: PT Raja Grafindo Parsada.

Pandia, Frianto. 2012. Manajemen Dana Dan Kesehatan Bank. Jakarta: PT Rineka Cipta.
R. Ade Sasongko Pramudhito. 2014. "Analisis pengaruh CAR, NPF, BOPO,FDR, dan NCOM terhadap Profitabilitas Bank Umum Syariah di Indonesia (Studi Kasus Pada Bank Umum Syarah di Indonesia Periode 2008-2012)." Skripsi, Universitas Diponegoro Semarang.

Rodiyah, Winda Aisyatur, and Sri Sulasmiyati. "Pengaruh Return On Investment (ROI), Return On Equity (ROE), Earning Per Share (EPS) Dan Economic Value Added (EVA) Terhadap Harga Saham (Studi Pada Perusahaan Sub Sektor Property Dan Real Estate Yang Terdaftar Di Bursa Efek Indonesia (BEI) Periode 2012 -." Jurnal Administrasi Bisnis 59, no. 1 (June 29, 2018).

Siregar, Budi Gautama. 2016.“Analisis Rasio Keuangan Dalam Menilai Kinerja Perusahaan."

Sofyan Mulazid, Ade. 2017. "Analisis Pengaruh DPK, NPF,CAR, Modal Inti dan Marjin Keuntungan Terhadap Pembiayaan Murabahah." Jurnal Ekonomi dan Bisnis Islam.

Sulhan dan Ely Siswanto. 2008. Manajemen Bank Konvensioanl dan Syariah. Malang: UIN Malang.

Wangsawidjaja Z, A. 2012. Pembiayaan Bank Syariah. Jakarta: PT Gramedia Pustaka Utama.

Washar, Yoga Mauluddin, and Suwitho. "Pengaruh Leverage Terhadap ROE Pada Perusahaan Property Dan Real Estate Yang Terdaftar Di BEI." Jurnal IImu Dan Rset Manajemen 8, no. 6 (2019).

Zulvia, Yolandafitri. 2020. "Faktor-Faktor yang Mempengaruhi Kinerja Keuangan Bank Syariah Indonesia." Jurnal Benefita 5, hlm. 53. 